\title{
Emisi gas rumah kaca, cadangan karbon serta strategi adaptasi dan mitigasi pada perkebunan kopi rakyat di Nusa Tenggara Barat
}

\author{
Greenhouse gas emission, carbon stock, adaptation and mitigation strategies at smallholder coffee \\ plantation in West Nusa Tenggara
}

\author{
Ali PRAMONO ${ }^{1 *)} \&$ SADMAKA $^{2)}$
}

\author{
${ }^{1)}$ Balai Penelitian Lingkungan Pertanian, Jalan Raya Jakenan-Jaken Km 5 Pati, 59182 Jawa Tengah, Indonesia \\ ${ }^{2)}$ Balai Perlindungan Tanaman Perkebunan, Dinas Pertanian dan Perkebunan Provinsi Nusa Tenggara Barat, Jl. Pejanggik \\ No.10 Kota Mataram, 83216 Nusa Tenggara Barat, Indonesia
}

Diterima tgl 23 Februari 2018/ disetujui tgl 21 September 2018

\begin{abstract}
Global warming and climate change are the world's major environmental, social and economic problems. The agricultural sector can act as an affected victim, greenhouse gas (GHG) contributor, and GHG absorber. Plantations have a very strategic role in the national action plan in GHG mitigation, because it has a great ability to absorb $\mathrm{CO}_{2}$. Therefore, it is necessary to determine the carbon stocks and GHG emissions from plantation management. The objectives of the study were to measure GHG emissions, to determine carbon stocks, and to define adaptation and mitigation strategies on climate change in existing coffee plantation systems. Gas samples were taken from 5 sampling points as replications by closed chamber method. Carbon stock estimation was done by destructive technique, including biomass of understorey and non-wood necromass. The results showed that the coffee plantations less than 10 years-old at the study sites emitted 47 tons $\mathrm{CO}_{2}$-e/halyear and stored carbon of 91.4 tons C/ha. Climate change adaptation strategies can be done by the application of good agricultural practices (GAP) and the use of drought-tolerant clones, mulches, shade trees, multiple cropping systems, silt pits and biophore techniques. The GHG mitigation can be done by the utilization of plantation waste as a source of organic fertilizer, biochar, animal feed, and bioenergy sources through the development of models of integration crop and livestock systems, as well as rejuvenation of plantation crops to increase carbon sinks and stocks.
\end{abstract}

[Keywords: climate change, carbon sequestration, coffee plantations]

\section{Abstrak}

Pemanasan global dan perubahan iklim menjadi masalah utama lingkungan, sosial dan ekonomi dunia hingga saat ini. Sektor pertanian dapat berperan sebagai korban terdampak, penyumbang Gas Rumah Kaca (GRK), dan penyerap GRK. Tanaman perkebunan mempunyai posisi sangat strategis dalam rencana aksi nasional di sektor pertanian, karena memiliki kemampuan besar dalam menyerap $\mathrm{CO}_{2}$. Oleh karena itu, pengukuran cadangan karbon dan emisi GRK dari pengelolaan perkebunan perlu dilakukan. Tujuan penelitian adalah untuk mengukur emisi GRK, menentukan cadangan karbon dan menetapkan strategi adaptasi dan mitigasi terhadap perubahan iklim pada sistem perkebunan kopi rakyat eksisting di Propinsi Nusa Tenggara Barat. Pengambilan contoh gas dilakukan di lima titik sampling dengan metode sungkup tertutup. Penghitungan cadangan karbon di atas permukaan tanah dilakukan dengan cara destruktif yang mencakup juga penetapan cadangan karbon biomassa tanaman bawah dan biomassa serasah (ne-kromas non kayu). Hasil penelitian menunjukkan bahwa perkebunan kopi rakyat yang berumur kurang dari 10 tahun di lokasi penelitian meng-emisikan karbon sebesar 47 ton $\mathrm{CO}_{2}-\mathrm{e} / \mathrm{ha} /$ tahun dan menyimpan cadangan karbon sebesar 91,4 ton $\mathrm{C} /$ ha. Strategi adaptasi terhadap perubahan iklim dapat dilakukan dengan penerapan praktik Pertanian yang baik/ Good Agricultural Practices (GAP), penggunaan klon tahan kekeringan, penggunaan mulsa organik, pemanfaatan pohon penaung dan sistem tumpang sari, pembuatan rorak dan biopori. Mitigasi GRK dapat dilakukan dengan pemanfaatan limbah tanaman perkebunan sebagai sumber pupuk organik, arang (biochar), pakan ternak, dan sumber bioenergi melalui pengem-bangan model sistem integrasi tanaman dan ternak, serta peremajaan tanaman perkebunan yang sudah menurun produktivitasnya untuk meningkatkan serapan dan cadangan karbon.

[Kata kunci : perubahan iklim, sekuestrasi karbon, perkebunan kopi]

\section{Pendahuluan}

Perubahan iklim disebabkan oleh meningkatnya gas rumah kaca (GRK) akibat kegiatan 
antropogenik dan non antropogenik. Suhu global telah meningkat sebesar $0,3-0,6{ }^{\circ} \mathrm{C}$ selama 100 tahun terakhir dan diperkirakan akan meningkat lebih lanjut $1-3,5{ }^{\circ} \mathrm{C}$ hingga tahun 2100 , disertai dengan perubahan curah hujan, pola badai, dan frekuensi kekeringan yang semakin sering (Kattenberg et al., 1996). Perubahan iklim dapat menyebabkan penurunan hasil tanaman dan mengancam keamanan pangan. Kenaikan suhu $1{ }^{\circ} \mathrm{C}$ dapat menurunkan hasil panen kopi arabika sebesar $137 \mathrm{~kg} / \mathrm{ha}$ (Craparo et al., 2015; OvalleRivera et al., 2015). Meningkatnya kejadian iklim ekstrim seperti kekeringan akibat El Nino menurunkan produksi kopi sebesar 10\%, sedangkan musim hujan panjang akibat La Nina menurunkan produksi hingga $80 \%$ (Syakir \& Surmaini, 2017). Peningkatan suhu udara juga dapat menyebabkan ledakan hama dan penyakit tanaman (Magina et al., 2011) sehingga sulit untuk menaikkan produksi kopi.

Konsentrasi GRK meningkat seiring dengan aktivitas manusia. Pertanian berkontribusi 10\% 12\% terhadap emisi GRK secara global (Smith et al., 2007). Kegiatan pertanian mengemisikan GRK berupa $\mathrm{CO}_{2}$ melalui konversi lahan serta pengelolaan tanah dan penggunaan energi, $\mathrm{N}_{2} \mathrm{O}$ yang bersumber dari kegiatan pemupukan, serta $\mathrm{CH}_{4}$ dari pengelolaan limbah organik (Flessa et al., 2002). Secara global, emisi $\mathrm{CH}_{4}$ dan $\mathrm{N}_{2} \mathrm{O}$ meningkat sebesar 17\% dari tahun 1990 hingga 2005 (Smith et al., 2007). Karbondioksida berkontribusi terbesar meningkatkan GRK dan pemanasan global. Saat ini konsentrasi $\mathrm{CO}_{2}$ di atmosfer mencapai 407 ppm dan konsentrasinya terus meningkat (ESRL, 2018). Dinitrogen oksida $\left(\mathrm{N}_{2} \mathrm{O}\right)$ merupakan GRK antropogenik yang berasal dari penggunaan pupuk dalam kegiatan pertanian dan kotoran ternak (Reay et al., 2012). Nitrogen yang terkandung dalam pupuk dan kotoran hewan meningkatkan proses nitrifikasi dan denitrifikasi secara alami. Bakteri berperan dalam proses tersebut di dalam tanah yang mengubah nitrogen menjadi gas $\mathrm{N}_{2} \mathrm{O}$ (Willey \& Chameides, 2007).

Tanaman kopi di Indonesia umumnya diusahakan oleh petani dalam bentuk perkebunan rakyat (smallholder). Produksi nasional kopi pada tahun 2015 adalah sebesar 639.412 ton (Ditjenbun, 2016). Kementerian Pertanian menargetkan produksi kopi pada tahun 2019 sebesar 0,79 juta ton, namun peningkatan produksinya masih rendah (Kementan, 2015). Berbagai penyebab rendahnya produktivitas kopi rakyat antara lain ialah teknik budidaya masih tradisional, tanaman banyak yang sudah tua, dan sebagian besar belum menggunakan klon unggul. Peluang untuk meningkatkan produksi dan produktivitas tanaman masih terbuka dengan menerapkan inovasi teknologi yang sesuai dengan kondisi agroekologi setempat. Disamping itu, teknologi tersebut harus mudah dan murah sehingga petani tidak sulit untuk mengadopsinya dengan cepat.

Pengelolaan lahan untuk pertanian menjadi salah satu sumber emisi $\mathrm{N}_{2} \mathrm{O}$. Emisi $\mathrm{N}_{2} \mathrm{O}$ dari tanah karena penggunaan pupuk kimia nitrogen yang terdapat pada pupuk urea dan ammonium sulfat menjadi $\mathrm{N}_{2} \mathrm{O}$ dan $\mathrm{NO}_{2}$. Penggunaan bahan organik merupakan komponen dalam konservasi sumber daya lahan pertanian berkelanjutan. Penambahan bahan organik ke dalam tanah berfungsi untuk meningkatkan sifat fisik, kimia, dan biologi tanah (Marinho et al., 2014). Akan tetapi, pemberian bahan organik dapat juga menyebabkan emisi GRK oleh proses seperti metanogenesis, nitrifikasi, dan denitrifikasi (Thangarajan et al., 2013).

Mitigasi GRK bertujuan untuk mengurangi emisi GRK terutama $\mathrm{N}_{2} \mathrm{O}$ dan $\mathrm{CH}_{4}$ dan meningkatkan penyerapan GRK atmosfer terutama $\mathrm{CO}_{2}$ dalam berbagai bentuk cadangan karbon (sink) dalam bahan organik tanah dan biomassa tanaman serta arang (biochar) (Barthod et al., 2016). Sektor pertanian berperan positif dalam membantu mengurangi $\mathrm{CO}_{2}$ di atmosfer, dengan cara menyerap dan menyimpan karbon dalam biomassa tanaman, dan meningkatkan kandungan karbon dalam tanah. Budidaya konservasi dapat menambah lebih banyak karbon yang dikembalikan ke lahan dan memperlambat laju proses konversi karbon dalam bahan organik menjadi gas $\mathrm{CO}_{2}$ (Smith \& Olesen, 2010; Hergoualc'h et al., 2012). Tujuan penelitian ini untuk mengukur emisi GRK, menentukan cadangan karbon dan menetapkan strategi adaptasi dan mitigasi terhadap perubahan iklim pada sistem perkebunan kopi rakyat eksisting di Propinsi Nusa Tenggara Barat.

\section{Bahan dan Metode}

\section{Lokasi penelitian}

Penelitian dilakukan di lahan perkebunan kopi rakyat Dusun Rumbuk, Desa Batu Mekar, Kecamatan Lingsar Kabupaten Lombok Barat, Propinsi Nusa Tenggara Barat. Pengambilan sampel GRK dan biomassa dilakukan pada tanggal 4-6 Agustus 2017. Kondisi lahan berlereng dengan ketinggian tempat berkisar 300$325 \mathrm{~m}$ dpl. Tipe penggunaan lahan di lokasi penelitian adalah lahan kopi muda yang berumur kurang dari 10 tahun dengan jarak tanam 2,5 x 2,5 $\mathrm{m}$, kebun campuran dengan tanaman pelindung sengon dan durian. Tanaman kopi sebagian besar sudah disambung pucuk dengan umur 2-3 tahun. Jenis kopi yang ditanam adalah robusta dan persentase jumlah tanaman kopi sekitar $70 \%$. Kondisi lahan ditumbuhi gulma yang didominasi gulma berdaun lebar.

\section{Pengukuran emisi GRK}

Pengambilan contoh gas di lapang dilakukan pada waktu pagi dan siang. Pengambilan contoh 
gas dilakukan di lima titik sampling pada jarak 25 meter dengan metode sungkup tertutup (close chamber) berukuran $20 \times 20 \times 40 \mathrm{~cm}^{3}$. Alat-alat yang digunakan antara lain adalah penampang dan sungkup. Sungkup mempunyai headspace yang merupakan ruang udara (Gambar 1).

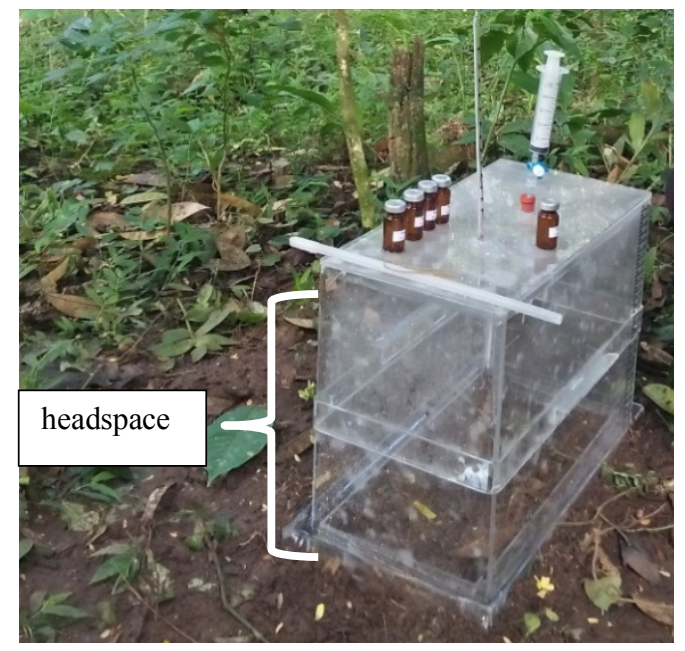

Gambar 1. Sungkup untuk pengambilan sampel GRK Figure 1. Close chamber for taking GHG samples

Pada bagian atas sungkup dilengkapi dengan lubang yang ditutup dengan septum untuk mengambil sampel gas serta lubang untuk tempat termometer. Waktu pengambilan sampel adalah pagi (pukul 07.00), dan siang hari (pukul 13.00). Pemasangan penampang sungkup dilakukan sehari sebelum pengambilan sampel. Pengambilan sampel gas di lapang dilakukan selama tiga hari berturut-turut. Penampang dipasang rata dengan permukaan tanah, kemudian diisi dengan air. Sungkup diletakkan di atas penampang dan dipastikan tidak ada kebocoran gas di bawah bagian sungkup. Termometer dipasang pada lubang yang ada pada bagian tutup/ atas sungkup. Penutup karet/ septum pada tempat pengambilan sampel udara dibuka \pm 2-3 menit agar konsentrasi udara dalam sungkup menjadi stabil. Setelah 2-3 menit, sumbat karet ditutupkan pada lubang septum. Gas diambil dengan menggunakan injektor (syringe) yang dipasang pada posisi tegak lurus pada karet septum tempat mengambil contoh gas. Interval waktu pengambilan contoh adalah 10, 20, 30, 40, dan 50 menit dalam satu rangkaian pengambilan contoh gas. Injektor ditutup dengan septum secepat mungkin untuk menghindari kebocoran atau kran syringe segera ditutup. Ketinggian air dari permukaan tanah dan perubahan suhu dalam sungkup selalu dicatat saat pengambilan contoh gas. Contoh gas segera dibawa ke laboratorium gas rumah kaca untuk analisis konsentrasi gas $\mathrm{N}_{2} \mathrm{O}$ dan $\mathrm{CO}_{2}$-nya. Perhitungan fluks dengan menggunakan rumus (1) berdasarkan metode International Atomic Energy Agency (IAEA, 1992).

$\mathrm{E}=\frac{d c}{d t} x \frac{V c h}{A c h} x \frac{m W}{m V} x 273,2 /(273,2+T) \ldots \ldots(1)$

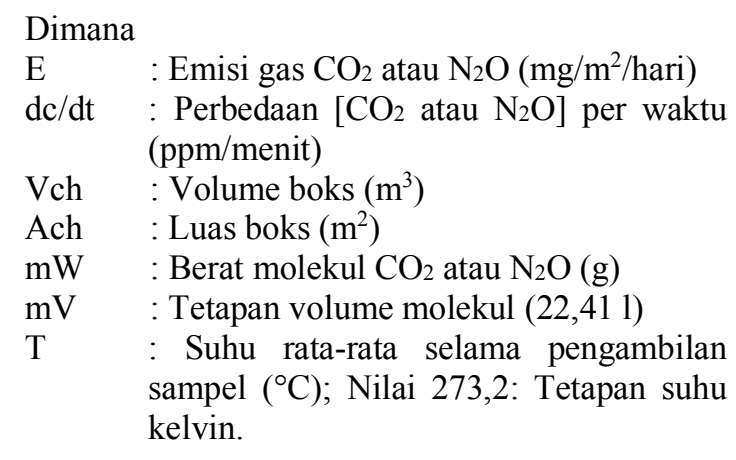

\section{Pengukuran cadangan karbon (C-Stock)}

Penghitungan cadangan karbon di atas permukaan tanah dilakukan dengan cara merusak biomassa (destructive), menimbang bobot kering biomassa, dan mengukur/ menganalisa kandungan karbon setiap bagian tanaman. Kemudian dilakukan juga penentuan cadangan karbon biomassa tanaman bawah (understorey) dan biomassa serasah (nekromas non kayu). Pengukuran parameter tanaman untuk keperluan perhitungan karbon stok tanaman terdapat pada Gambar 2. Perhitungan cadangan karbon yang terdapat dalam tanaman menggunakan rumus (2) (Hairiah et al., 2011).

Cadangan karbon $=$ Berat Kering biomassa $\mathrm{x} \% \mathrm{C}$ Organik tanaman.

Pengukuran cadangan karbon juga dilakukan dengan cara tanpa merusak biomassa tanaman (non destructive) (Hairiah et al., 2011), yaitu dengan cara mengukur contoh tanaman, identifikasi jenis tanaman, kemudian dihitung dengan menggunaan persamaan alometrik (Tabel 1). Tahap pengukuran cadangan karbon meliputi pembuatan plot contoh pengukuran, pengukuran biomassa tanaman (destructive dan non destructive), pengukuran nekromas, persentasi kandungan karbon tanaman, dan berat kering tanaman yang diukur di laboratorium, serta kandungan karbon suatu penggunaan lahan dapat diestimasi.

\section{Pengukuran biomassa tanaman}

Pengukuran biomassa tanaman dilakukan dengan mencatat nama semua pohon yang ada dalam Sub Plot dalam blanko yang tersedia. Keliling pohon untuk semua pohon yang berada dalam Sub Plot diukur dengan menggunakan meteran. Jika terdapat pohon dengan diameter $>$ $30 \mathrm{~cm}$ atau keliling $>94 \mathrm{~cm}$, harus dibuat Plot Besar. Nama semua pohon yang berdiameter $>30$ $\mathrm{cm}$ dicatat, dan diameter of breast height $(\mathrm{dbh})$ untuk semua pohon dengan diameter $>30 \mathrm{~cm}$ diukur.

\section{Pengukuran tanaman bawah (understorey)}

Semua tanaman bawah dan pohon yang berdiameter $<5 \mathrm{~cm}$, yang berada di dalam Sub Sub Plot (6 contoh) diambil contoh tanamannya dan dimasukkan ke dalam kantong kertas. Berat 
basah dari tanaman (daun dan batang dipisahkan) ditimbang. Sub contoh tanaman dari masingmasing biomassa daun, batang sekitar 100-300 gram diambil dan dikeringkan untuk dianalisis persen kandungan $\mathrm{C}$ tanaman di laboratorium. Berat kering oven $\left(105^{\circ} \mathrm{C}\right)$ dan persen karbon tanamannya dicatat.

\section{Pengukuran nekromas/ serasah tanaman}

Semua serasah di dalam Sub Sub Plot (6 contoh) diambil dan dimasukkan ke dalam kantong, kemudian berat serasah ditimbang. Sub contoh serasah dari masing-masing Sub Sub Plot diambil sekitar 100-300 gram dan dikeringkan dan dianalisis untuk penetapan persen kandungan $\mathrm{C}$ tanaman di laboratorium.

\section{Hasil dan Pembahasan}

\section{Emisi GRK}

Hasil pengukuran fluks (emisi gas harian) $\mathrm{N}_{2} \mathrm{O}$ sebesar $0,99 \mathrm{mg} / \mathrm{m}^{2} /$ hari dan $\mathrm{CO}_{2}$ sebesar 12.586 $\mathrm{mg} / \mathrm{m}^{2} /$ hari (Tabel 2 dan 3). Perbedaan rata-rata hasil pengukuran antara pagi dan siang sangat kecil. Hal ini disebabkan karena perbedaan kondisi lingkungan (suhu dan kelembaban) antara pagi dan siang relatif kecil. Pada pagi hari ratarata suhu berkisar $21,2-22,3{ }^{\circ} \mathrm{C}$ dan pada siang hari sekitar $23,3-24,2^{\circ} \mathrm{C}$. Hasil perhitungan total emisi gas $\mathrm{N}_{2} \mathrm{O}$ dari lahan perkebunan tersebut sebesar 2,29 $\mathrm{kg} \mathrm{N} \mathrm{N}_{2} \mathrm{O}-\mathrm{N} / \mathrm{ha} /$ tahun atau sebesar $1.073 \mathrm{~kg} \mathrm{CO}$-e/ha/tahun. Besaran emisi tersebut lebih kecil bila dibandingkan dengan emisi pada perkebunan kopi di Sumber Jaya, Lampung (Verchot et al., 2006). Dari lahan yang ditanami kopi berumur 1 tahun tersebut, emisi $\mathrm{N}_{2} \mathrm{O}$ terukur sebesar 8,4 $\mathrm{kg} \mathrm{N} \mathrm{N}_{2} \mathrm{O}-\mathrm{N} / \mathrm{ha} /$ tahun. Tanah hutan hujan tropis yang ditanami karet dan dipupuk menghasilkan emisi $\mathrm{N}_{2} \mathrm{O}$ sebesar $6,28 \mathrm{~kg} \mathrm{~N} \mathrm{~N}_{2} \mathrm{O}-$ $\mathrm{N} /$ ha/tahun, sedangkan dari tanah yang tidak dipupuk hanya mengemisikan $\mathrm{N}_{2} \mathrm{O}$ sebesar 3,93 $\mathrm{kg} \mathrm{N}_{2} \mathrm{O}-\mathrm{N} /$ ha/tahun (Zhou et al., 2016). Berdasarkan Hergoualc'h et al. (2008) bahwa besaran emisi $\mathrm{N}_{2} \mathrm{O}$ tergantung dari pemberian pupuk nitrogen $(\mathrm{N})$, kandungan $\mathrm{N}$, kelembaban tanah, suhu dan lain-lain. Kandungan $\mathrm{N}$ yang berasal dari serasah tanaman di tanah juga mempengaruhi besaran emisi $\mathrm{N}_{2} \mathrm{O}$. Hergoualc'h et al. (2012) menyatakan bahwa tanaman kopi dengan sistem agroforestri (dengan tanaman leguminose: Inga densiflora) memiliki emisi $\mathrm{N}_{2} \mathrm{O}$ lebih tinggi dibandingkan dengan emisi dari tanaman kopi dengan sistem monokultur karena pada sistem agroforestri mineralisasi $\mathrm{N}$ tanah dan $\mathrm{N}$ serasah lebih tinggi. Emisi $\mathrm{N}_{2} \mathrm{O}$ lebih besar dari tanah yang terlindung tanaman yang lebih tinggi. Pemupukan anorganik merupakan faktor yang paling dominan dalam menghasilkan emisi $\mathrm{N}_{2} \mathrm{O}$ (Munoz et al., 2010).

Total emisi $\mathrm{CO}_{2}$ pertahun dari lahan pertanaman kopi sebesar 45,9 ton $\mathrm{CO}_{2} /$ ha/tahun. Emisi $\mathrm{CO}_{2}$ berasal dari proses biotik dan abiotik yang berkaitan dengan aktivitas perakaran tanaman dan respirasi organisme (Berisso et al., 2013; Hanson et al., 2000). Proses tersebut sangat dipengaruhi oleh suhu, kelembaban, tekstur, dan agregasi tanah (Blagodatsky \& Smith, 2012; Wu et al., 2010). Peningkatan suhu tanah berpengaruh terhadap perubahan respirasi akar dan laju dekomposisi bahan organik (Peng et al., 2009).

Kelembaban tanah merupakan faktor utama dalam mempengaruhi aktivitas mikroorganisme (Brocket et al., 2012). Pada penelitian ini, perbedaan besaran emisi yang kecil antara pagi dan siang hari karena suhu dipengaruhi oleh adanya tanaman naungan, terutama tanaman sengon. Tanaman naungan bermanfaat mengurangi penyinaran pada tanaman sehingga perbedaan suhu tanah antara pagi dan siang sangat kecil.

Emisi GRK dari lahan perkebunan ini didominasi oleh gas $\mathrm{CO}_{2}$. Kontribusi $\mathrm{N}_{2} \mathrm{O}$ terhadap keseluruhan emisi GRK pada lahan perkebunan ini adalah 2\%. Bila dijumlahkan, potensi pemanasan global/ Global Warming Potential (GWP) dari gas $\mathrm{N}_{2} \mathrm{O}$ dan $\mathrm{CO}_{2}$ yang diemisikan tersebut sebesar 47 ton $\mathrm{CO}_{2}-$ e/ha/tahun. Nilai GWP tersebut cukup besar untuk tanah mineral. Hal ini mungkin karena tingginya bahan organik (kadar C-organik sebesar 3\%) dalam tanah sehingga proses dekomposisi berlangsung cepat yang menghasilkan $\mathrm{CO}_{2}$. Dalam pengelolaan perkebunan kopi rakyat tersebut, petani memberi pupuk organik saja dengan takaran $10 \mathrm{~kg} /$ pohon dan diberikan 2 kali dan tanpa pemberian pupuk anorganik.

Tabel 1. Estimasi biomassa pohon menggunakan persamaan alometrik (Hairiah et al., 2011)

Table 1. Tree biomass estimation using allometric equation (Hairiah et al., 2011)

\begin{tabular}{|c|c|}
\hline $\begin{array}{c}\text { Jenis Pohon } \\
\text { Plants }\end{array}$ & $\begin{array}{l}\text { Estimasi Biomassa pohon ( } \mathrm{kg} / \text { pohon }) \\
\text { Tree biomass estimation ( } \mathrm{kg} / \text { plant) }\end{array}$ \\
\hline Pohon bercabang/ Branched structure & $\mathrm{BK}=0,11 \rho \mathrm{D}^{2.62}$ \\
\hline Pohon tidak bercabang/ Unbranched structure & $\mathrm{BK}=\pi \rho \mathrm{H}^{*} \mathrm{D}^{2} / 40$ \\
\hline Kopi pangkas/Coffee & $\mathrm{BK}=0,281 \mathrm{D}^{2.06}$ \\
\hline Pisang/Banana & $\mathrm{BK}=0,030 \mathrm{D}^{2.13}$ \\
\hline Bambu/Bamboo & $\mathrm{BK}=0,031 \mathrm{D}^{2.28}$ \\
\hline Sengon /Albizia & $\mathrm{BK}=0,0272 \mathrm{D}^{2.831}$ \\
\hline Pinus/Pinus & $\mathrm{BK}=0,0417 \mathrm{D}^{2.6576}$ \\
\hline Kelapa sawit/Elaeis & $\mathrm{BK}=\left(0,0976 \times \mathrm{H}^{* *}\right)+0.0706$ \\
\hline
\end{tabular}




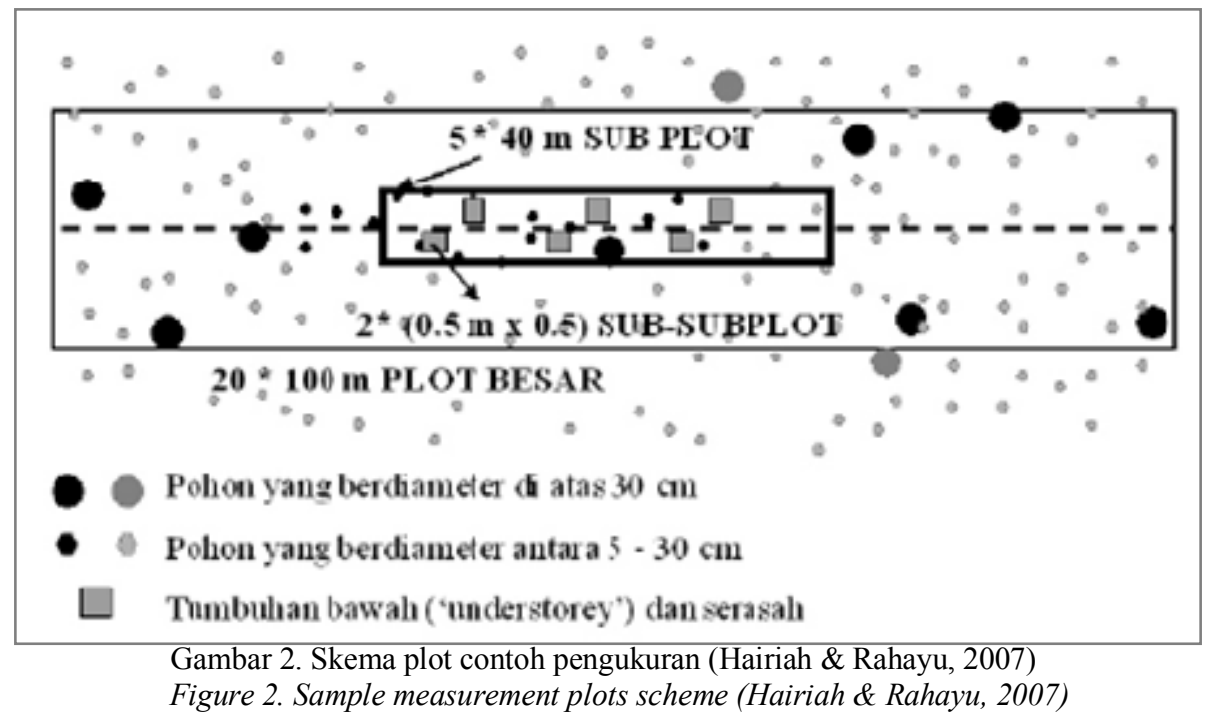

Tabel 2. Fluks harian $\mathrm{N}_{2} \mathrm{O}$ dan $\mathrm{CO}_{2}$ pada lahan perkebunan kopi rakyat di Nusa Tenggara Barat Table 2. Daily $\mathrm{N}_{2} \mathrm{O}$ and $\mathrm{CO}_{2}$ fluxes in smallholder coffee plantation in West Nusa Tenggara

\begin{tabular}{|c|c|c|c|c|c|c|}
\hline \multirow{3}{*}{ Titik/Points } & \multicolumn{2}{|c|}{ Hari I/Day I } & \multicolumn{2}{|c|}{ Hari II/Day II } & \multicolumn{2}{|c|}{ Hari III/Day III } \\
\hline & $\mathrm{N}_{2} \mathrm{O}$ & $\mathrm{CO}_{2}$ & $\mathrm{~N}_{2} \mathrm{O}$ & $\mathrm{CO}_{2}$ & $\mathrm{~N}_{2} \mathrm{O}$ & $\mathrm{CO}_{2}$ \\
\hline & & & $---(\mathrm{mg}$ & i)-------- & ----- & -- \\
\hline \multicolumn{7}{|c|}{ A. Pagi/Morning } \\
\hline 1 & 0,56 & 14.286 & 0,76 & 12.248 & 0,77 & 15.022 \\
\hline 2 & 1,13 & 13.489 & 1,21 & 11.233 & 0,67 & 10.380 \\
\hline 3 & 0,86 & 13.448 & 1,20 & 11.814 & 1,08 & 11.500 \\
\hline 4 & 0,63 & 14.158 & 1,68 & 14.276 & 1,04 & 13.229 \\
\hline 5 & 0,59 & 9.878 & 1,66 & 13.562 & 1,16 & 14.265 \\
\hline Rata-rata/average & 0,76 & 13.052 & 1,30 & 12.627 & 0,94 & 12.879 \\
\hline \multicolumn{7}{|c|}{ B. Siang/Afternoon } \\
\hline 1 & 0,94 & 10.132 & 0,62 & 12.951 & 1,04 & 7.278 \\
\hline 2 & 0,50 & 12.306 & 0,89 & 13.947 & 1,24 & 14.169 \\
\hline 3 & 1,31 & 12.200 & 1,22 & 12.342 & 0,62 & 13.662 \\
\hline 4 & 1,93 & 10.654 & 0,89 & 8.234 & 0,54 & 13.688 \\
\hline 5 & 1,11 & 13.413 & 0,91 & 15.439 & 0,81 & 14.361 \\
\hline Rata-rata/average & 1,16 & 11.741 & 0,91 & 12.583 & $\mathbf{0 , 8 5}$ & 12.632 \\
\hline
\end{tabular}

Pemberian bahan organik dilakukan dengan cara membumbunkannya pada daerah perakaran secara melingkar dengan takaran $5 \mathrm{~kg} /$ pohon, dilakukan pada awal dan akhir musim penghujan.

\section{Cadangan karbon dari lahan perkebunan kopi rakyat}

Kegiatan mitigasi bertujuan untuk mengurangi emisi gas rumah kaca melalui strategi penurunan emisi gas rumah kaca dan peningkatan penyerapan $\mathrm{CO}_{2}$ dan cadangan karbon. Tanaman perkebunan mempunyai posisi sangat strategis dalam rencana aksi nasional mitigasi GRK di sektor pertanian, karena memiliki kemampuan besar dalam menyerap $\mathrm{CO}_{2}$. Disamping itu, pemberian bahan organik ke dalam tanah juga merupakan salah satu cara untuk menyimpan karbon (Abera \& Meskel, 2013) dan meningkatkan cadangan karbon tanah (Li et al., 2015). Asumsi yang digunakan dalam penelitian ini, dalam bahan organik tersebut terkandung 20\% karbon, kadar air $80 \%$, dan karbon yang tertinggal di dalam tanah 50\%. Besarnya cadangan karbon yang terhitung dalam penelitian ini adalah sebagai berikut:

- $\quad$ Biomassa pohon $=909 \mathrm{~kg} \mathrm{C}\left(5 \times 20 \mathrm{~m}^{2}\right)=$ $90.900 \mathrm{~kg} \mathrm{C} / \mathrm{ha}$ (Tabel 3)

- Berat kering tumbuhan bawah dan serasah = $13,1 \mathrm{gr} / \mathrm{m}^{2}=131 \mathrm{~kg} /$ ha (Tabel 4).

Jumlah cadangan karbon yang ditunjukkan oleh tumbuhan bawah dan serasah memang lebih kecil dibandingkan dengan jumlah cadangan karbon dari biomassa pohon. Hal ini disebabkan dari ukuran, tumbuhan bawah jauh lebih kecil dan intensitas cahaya matahari yang didapatkan juga kurang optimal.

Jenis pohon yang mendominasi sistem agroforestri di lokasi penelitian yaitu kopi. Tanaman ini dipilih karena mendukung mata pencaharian yang sebagian besarnya adalah sebagai petani kopi. Tanaman kopi termasuk tanaman yang tahan terhadap naungan, mudah dipelihara dan berbuah setiap saat. Di samping itu juga kayunya dapat dimanfaatkan untuk dijual sebagai kayu bakar, terutama jika produksi tanaman kopi mengalami penurunan. Meskipun 
tanaman kopi mendominasi, namun jumlah biomassanya paling kecil dibandingkan dengan tanaman sengon dan durian, namun persentase biomassa tanaman kopi hanya $0,7 \%$ dari total biomassa. Tanaman sengon mendominasi jumlah biomassa karena dipertahankan sebagai penaung dan seharusnya memerlukan peremajaan tanaman. Jumlah cadangan karbon di lokasi penelitian dapat dihitung sebagai berikut:

- $\quad$ Biomassa pohon $=90.900 \times 44 / 12 \mathrm{~kg} \mathrm{CO}_{2}$-e per ha $=333.415 \mathrm{~kg} \mathrm{CO}_{2}-\mathrm{e} / \mathrm{ha}$

- $\quad$ Tumbuhan bawah dan serasah $=131 \times 0,46$ x 44/12 = 220,9 $\mathrm{kg} \mathrm{CO}_{2}$-e/ha

- $\quad$ Pemberian pupuk organik $=10 \mathrm{~kg} /$ pohon $\mathrm{x}$ $2000 \mathrm{pohon} / \mathrm{ha} \times 20 / 100 \times 20 / 100 \times 50 / 100 \times$ $44 / 12=1.467 \mathrm{~kg} \mathrm{CO}_{2}$-e/ha

- $\quad$ Total sekuestrasi karbon $=335.103 \mathrm{~kg} \mathrm{CO}$ $\mathrm{e} / \mathrm{ha}=335$ ton $\mathrm{CO}_{2}$-e/ha $=91,4$ ton $\mathrm{C} / \mathrm{ha}$

Dengan demikian, terdapat karbon netto yaitu emisi dikurangi cadangan karbonnya sebesar 47 $335=-288$ ton $\mathrm{CO}_{2}-\mathrm{e} / \mathrm{ha}$. Hal ini berarti bahwa, kegiatan perkebunan kopi tersebut menyerap (sekuestrasi) karbon sebesar 288 ton $\mathrm{CO}_{2}$-e /ha. Dengan penaung tanaman sengon dan durian ini, cadangan karbon di lokasi penelitian sebesar 91,4 ton $\mathrm{C} /$ ha. Hasil penelitian Wibawa et al. (2010) menunjukkan bahwa pada kebun kopi monokultur dengan penaung lamtoro, cadangan karbon lebih rendah daripada sistem agroforestri. Cadangan karbon rata-rata kopi robusta pada umur 30 tahun adalah 29,4 ton/ha. Pada per- kebunan rakyat dan perkebunan besar, cadangan karbon berkisar antara 7,5 hingga 76,4 ton $\mathrm{C} /$ ha tergantung umur tanaman. Dengan sistem agroforestri, cadangan karbon pada tanaman kopi berumur 2-30 tahun dapat mencapai 92 ton $\mathrm{C} /$ ha (van Noor Wijk et al., 2002).

Jejak karbon pada suatu cara budidaya berguna untuk mengetahui apakah cara tersebut menambah atau mengurangi emisi karbon. Hasil penelitian Noponen et al. (2012) menunjukkan bahwa jejak karbon dari $1 \mathrm{~kg}$ biji kopi basah berkisar antara $0,26-0,67 \mathrm{~kg} \mathrm{CO}_{2}$-e untuk sistem konvensional dan $0,12-0,52 \mathrm{~kg} \mathrm{CO}_{2}$-e untuk sistem pengelolaan organik. Hal ini berarti bahwa sistem pengelolaan kopi secara organik merupakan kegiatan yang ramah lingkungan karena mengemisikan GRK lebih rendah.

Adaptasi dan mitigasi terhadap perubahan iklim pada lahan perkebunan kopi

Strategi adaptasi dan mitigasi terhadap perubahan iklim perlu dilakukan untuk mengurangi emisi GRK dan atau meningkatkan cadangan karbon yang rendah. Strategi tersebut dapat dilakukan dengan cara menerapkan Good Agriculture Practices (GAP), yaitu dengan budidaya tanaman secara tepat dan benar, produksi tinggi, mutu produk baik, keuntungan optimal dan ramah lingkungan serta dengan memperhatikan aspek keamanan dan kesejahteraan petani. Beberapa teknologi adaptasi

Tabel 3. Cadangan karbon pada biomassa tanaman/pohon (dalam plot berukuran $5 \mathrm{~m}$ x $20 \mathrm{~m}$ )

Table 3. Carbon stock on tree biomass (in plot size $5 \mathrm{~m} \times 20 \mathrm{~m}$ )

\begin{tabular}{cccccccc}
\hline No & $\begin{array}{c}\text { Nama Pohon/ } \\
\text { Tree } \text { name }\end{array}$ & $\begin{array}{c}\text { Keliling/ } \\
\text { Circumference } \\
(\mathrm{cm})\end{array}$ & $\begin{array}{c}\text { Tinggi } \\
\text { Pohon/ } \\
\text { Length } \\
(\mathrm{cm})\end{array}$ & $\begin{array}{c}\rho \\
\left(\mathrm{g} / \mathrm{cm}^{3}\right)\end{array}$ & $\begin{array}{c}\text { Diameter/ } \\
\text { Diameter } \\
(\mathrm{cm})\end{array}$ & $\begin{array}{c}\text { Berat kering } \\
\text { (kg/pohon)/ } \\
\text { Dry weight } \\
(\mathrm{kg} / \text { plant })\end{array}$ & $\begin{array}{c}\text { C-tanaman } \\
(\mathrm{kg} \text { C/pohon)/ } \\
\text { C biomass } \\
(\mathrm{kg} / \text { plant })\end{array}$ \\
\hline 1 & Durian/Durian & 75 & 1000 & 0,64 & 23,885 & 216,800 & 99,728 \\
2 & Durian/ Durian & 75 & 1000 & 0,64 & 23,885 & 216,800 & 99,728 \\
3 & Sengon/Albizia & 150 & 2000 & 0,55 & 47,771 & 1542,678 & 709,632 \\
4 & Kopi/Coffee & 3 & 150 & & 0,955 & 0,025 & 0,011 \\
5 & Kopi/Coffee & 3 & 150 & & 0,955 & 0,025 & 0,011 \\
6 & Kopi/Coffee & 3 & 150 & & 0,955 & 0,025 & 0,011 \\
7 & Kopi/Coffee & 3 & 150 & & 0,955 & 0,025 & 0,011 \\
8 & Kopi/Coffee & 3 & 150 & & 0,955 & 0,025 & 0,011 \\
9 & Kopi/Coffee & 3 & 150 & & 0,955 & 0,025 & 0,011 \\
10 & Kopi/Coffee & 3 & 150 & & 0,955 & 0,025 & 0,011 \\
11 & Kopi/Coffee & 3 & 150 & & 0,955 & 0,025 & 0,011 \\
12 & Kopi/Coffee & 3 & 150 & & 0,955 & 0,025 & 0,011 \\
13 & Kopi/Coffee & 3 & 150 & & 0,955 & 0,025 & 0,011 \\
14 & Kopi/Coffee & 3 & 150 & & 0,955 & 0,025 & 0,011 \\
15 & Kopi/Coffee & 3 & 150 & & 0,955 & 0,025 & 0,011 \\
16 & Kopi/Coffee & 3 & 150 & & 0,955 & 0,025 & 0,011 \\
17 & Kopi/Coffee & 3 & 150 & & 0,955 & 0,025 & 0,011 \\
18 & Kopi/Coffee & 3 & 150 & & 0,955 & 0,025 & 0,011 \\
19 & Kopi/Coffee & 3 & 150 & & 0,955 & 0,025 & 0,011 \\
20 & Kopi/Coffee & 3 & 150 & & 0,955 & 0,025 & 0,011 \\
21 & Kopi/Coffee & 3 & 150 & & 0,955 & 0,025 & 0,011 \\
22 & Kopi/Coffee & 3 & 150 & & 0,955 & 0,025 & 0,011 \\
23 & Kopi/Coffee & 3 & 150 & & 0,955 & 0,025 & 0,011 \\
& Total (kg)/Total & & & & 909,316
\end{tabular}

Keterangan: $\mathrm{BK}=$ berat kering $(\mathrm{g}) ; \mathrm{D}=$ diameter pohon $(\mathrm{cm}) ; \mathrm{H}^{*}=$ tinggi pohon $(\mathrm{cm}) ; \mathrm{H}^{* *}=$ tinggi pohon $(\mathrm{m}) ; \rho=$ berat jenis kayu $\left(\mathrm{g} / \mathrm{cm}^{3}\right)$ Notes: $B K=d r y$ weight $(\mathrm{g}) ; \quad D=$ tree diameter (cm); $H^{*}=$ length $(\mathrm{cm}) ; \quad H^{* *}=$ length $(\mathrm{m}) ; \quad \rho=$ wood density $\left(\mathrm{g} / \mathrm{cm}^{3}\right)$ 
dan mitigasi terhadap dampak perubahan iklim yang telah diaplikasikan di lokasi penelitian adalah pola agroforestri (pola tanam dengan tanaman penaung), penggunaan klon adapatif seperti klon tahan kekeringan, dan teknologi konservasi tanah dengan pemberian pupuk organik. Pengelolaan hutan rakyat dengan pola agroforestri mempunyai potensi yang besar untuk menyerap dan menyimpan karbon dalam bentuk tegakan dalam jangka waktu yang lama. Penggunaan bibit kopi dengan batang bawah klon unggul dengan perakaran kuat mampu meningkatkan ketahanan tanaman terhadap kekeringan dan penurunan kesuburan tanah. Kopi robusta merupakan jenis kopi yang tahan kekeringan, karena memiliki perakaran yang lebat.

Penggunaan lebih banyak pohon penaung, yang juga dapat meningkatkan daya tahan petani terhadap dampak perubahan iklim untuk memberikan subsitusi produk yang bernilai secara ekonomi, seperti tanaman buah-buahan. Penggunaan tanaman leguminosa sebagai penaung juga disarankan karena dapat mengurangi penggunaan pupuk kimia dan meningkatkan ketersediaan nitrogen di tanah yang ditambat oleh tanaman tersebut, serta mampu beradaptasi pada zona agroekologi yang luas (Muelenberg \& Dakora, 2007). Tanaman penaung juga dapat membantu meningkatkan kesuburan tanah. Selain memberikan perlindungan terhadap lingkungan, tanaman penaung dapat meningkatkan ekonomi rumah tangga serta sebagai alternatif dalam mengatasi anjloknya harga kopi. Efisiensi penggunaan pupuk juga menjadi hal yang penting dalam mengurangi emisi gas rumah kaca (Balafoutis et al., 2017). Mayoritas petani menggunakan pupuk di bawah standar yang direkomendasikan yang tidak secara signifikan berdampak pada peningkatan produksi, namun meningkatkan emisi gas rumah kaca ke atmosfer. Pemangkasan dilakukan secara selektif dengan membuang bagian tanaman yang tidak produktif yang kemudian akan mengurangi tingkat transpirasi dan secara tidak langsung mempertahankan kandungan air tanah (Lin, 2010).

Untuk mengantisipasi dampak kekeringan, perlu upaya menyimpan dan mempertahankan lengas tanaman. Agar lengas tanah cukup tersedia, maka perlu dilakukan usaha penyimpanan lengas. Bahan penyimpanan lengas tanah yang sangat baik di dalam tanah adalah bahan organik. Daya simpan kelembaban tanah oleh bahan organik sangat besar, sehingga tanah yang kadar bahan organiknya tinggi memiliki daya simpan lengas yang tinggi pula. Bahan organik dapat berupa pupuk kandang dan pupuk kompos yang berasal dari limbah organik asal lahan. Pada musim kemarau yang panjang disarankan untuk memberikan mulsa baik berupa jerami, pangkas dedaunan pohon penaung, serasah dedaunan maupun cacahan kayu. Mulsa ditebar sekitar $15-20 \mathrm{~cm}$ pada piringan tanaman. Secara bertahap bahan mulsa ini akan terdekomposisi sehingga menambah kadar bahan organik dalam tanah (Abdoellah, 2016). Bahan alami yang mudah terurai seperti daun dan kulit kopi, serasah pangkasan dan tanaman penaung juga dapat digunakan sebagai mulsa organik (Syakir \& Surmaini, 2017). Selain itu mulsa dapat menahan erosi dan sekaligus mengkonservasi (Suryani \& Dariah, 2012). Mulsa ini dapat bertahan lebih lama sebagai mulsa pada musim kemarau sebab tidak ada kelembaban yang memicunya untuk terdekomposisi. Penanaman varietas yang tahan kekeringan, tumpang sari tanaman kopi dan pisang, pemanenan air hujan juga merupakan langkah konservasi, adaptasi dan mitigasi terhadap perubahan iklim (Alemu \& Dufera, 2017). Pembuatan rorak juga akan memperbesar resapan air ke tanah dan menampung tanah yang tererosi, unsur hara yang terbawa erosi meresap di sekitar perakaran tanaman, menampung bahan organik dan merangsang pembentukan akar serabut tanaman kopi sehingga penyerapan hara lebih optimal (Yuliasmara, 2016). Teknik biopori juga dapat diterapkan untuk meresapkan dan menyimpan air yang cukup efektif pada areal pertanaman kopi (Syakir \& Surmaini, 2017).

Pemupukan merupakan suatu usaha untuk mencukupi kebutuhan hara bagi tanaman agar tumbuh dan memberikan hasil yang memadai. Pemberian pupuk organik sangat disarankan untuk mengantisipasi terhadap kekeringan, karena dengan adanya kandungan organik dalam tanah akan lebih banyak menyimpan air dan memperbaiki sifat bilogi tanah (Ayalev, 2014; Velmourougane, 2016). Penggunaan pupuk organik dengan cara yang efisien memberikan dampak positif terhadap penurunan emisi gas (Graham et al., 2017). Sistem pengelolaan organik menurunkan emisi per $\mathrm{kg}$ kopi yang dihasilkan (Noponen et al., 2012). Hasil kegiatan ini tidak hanya relevan untuk perkebunan kopi namun juga komoditas perkebunan lainnya. Penggunaan pupuk kimia secara tidak tepat tanpa adanya kombinasi dengan pupuk organik menjadi salah satu sumber emisi $\mathrm{N}_{2} \mathrm{O}$. Selain itu, pemanfaatan tanaman penambat $\mathrm{N}$ dari udara adalah cara lain mengurangi ketergantungan penggunaan pupuk kimia pada perkebunan. Kegiatan mitigasi yang dapat diterapkan antara lain adalah pengelolaan tanah dan tanaman yang baik dengan memanfaatkan limbah tanaman perkebunan sebagai sumber pupuk organik, arang (biochar), pakan ternak, dan sumber bioenergi melalui pengembangan model sistem integrasi tanaman dan ternak (SITT), sehingga dapat meminimalkan emisi GRK dan meningkatkan serapan dan cadangan karbon. 
Tabel 4. Berat kering tumbuhan bawah dan serasah dalam plot kecil $(0,5 \mathrm{~m} \times 0,5 \mathrm{~m})$

Table 4. Dry weight of understorey and necromass in small plot $(0.5 \mathrm{~m} \times 0.5 \mathrm{~m})$

\begin{tabular}{|c|c|c|c|c|c|c|c|c|}
\hline \multirow[t]{2}{*}{ No } & \multirow[t]{2}{*}{ Vegetasi/ Vegetation } & \multicolumn{2}{|c|}{$\begin{array}{l}\text { Berat Basah / } \\
\text { Fresh weight } \\
\quad(\mathrm{g})\end{array}$} & \multicolumn{2}{|c|}{$\begin{array}{c}\text { Sub contoh berat } \\
\text { basah/ } \\
\text { Fresh weight of sub } \\
\text { plot } \\
\text { (g) }\end{array}$} & \multicolumn{2}{|c|}{$\begin{array}{l}\text { Sub contoh berat } \\
\text { kering/ } \\
\text { Dry weight of sub } \\
\text { plot } \\
(\mathrm{g}) \\
\end{array}$} & \multirow[t]{2}{*}{$\begin{array}{c}\text { Total berat } \\
\text { kering / Dry } \\
\text { weight total } \\
\left(\mathrm{g} / \mathrm{m}^{2}\right)\end{array}$} \\
\hline & & $\begin{array}{l}\text { Daun/ } \\
\text { Leaf }\end{array}$ & $\begin{array}{l}\text { Batang/ } \\
\text { Stem }\end{array}$ & $\begin{array}{c}\text { Daun/ } \\
\text { Leaf }\end{array}$ & $\begin{array}{l}\text { Batang/ } \\
\text { Stem }\end{array}$ & $\begin{array}{l}\text { Daun/ } \\
\text { Leaf }\end{array}$ & $\begin{array}{l}\text { Batang/ } \\
\text { Stem }\end{array}$ & \\
\hline 1 & $\begin{array}{l}\text { Understorey 1/ } \\
\text { Understorey } 1\end{array}$ & 1,25 & 1,6 & 1,25 & 0,6 & 0,7 & 0,9 & 1,6 \\
\hline 2 & $\begin{array}{l}\text { Understorey } 2 / \\
\text { Understorey } 2\end{array}$ & 1,7 & & 1,7 & & 1,1 & & 1,1 \\
\hline 3 & $\begin{array}{l}\text { Understorey } 3 / \\
\text { Understorey } 3\end{array}$ & 1,1 & 2,5 & 1,1 & 0,5 & 0,7 & & 0,7 \\
\hline 4 & $\begin{array}{l}\text { Understorey 4/ } \\
\text { Understorey } 4\end{array}$ & 1,7 & & 1,7 & & 0,8 & 1,6 & 2,4 \\
\hline 5 & $\begin{array}{l}\text { Understorey } 5 / \\
\text { Understorey } 5\end{array}$ & 1,1 & & 1,1 & & 0,6 & & 0,6 \\
\hline 6 & $\begin{array}{l}\text { Understorey } 6 / \\
\text { Understorey } 6\end{array}$ & 1,2 & & 1,2 & & 0,7 & & 0,7 \\
\hline 7 & Serasah 1/Necromass 1 & 1,1 & & 1,1 & & 0,6 & & 0,6 \\
\hline 8 & Serasah 2/ Necromass 2 & 1,25 & & 1,25 & & 0,7 & & 0,7 \\
\hline 9 & Serasah 3/ Necromass 3 & 1,9 & & 1,9 & & 01.02 & & 0,0 \\
\hline 10 & Serasah 4/ Necromass 4 & 2,3 & & 2,3 & & 1,6 & & 1,6 \\
\hline 11 & Serasah 5/ Necromass 5 & 2,1 & & 2,1 & & 1,5 & & 1,5 \\
\hline 12 & $\begin{array}{l}\text { Serasah } 6 / \text { Necromass } 6 \\
\text { Sub Total }\left(\mathrm{g} / \mathrm{m}^{2}\right)\end{array}$ & 1,9 & & 1,9 & & 1,6 & & $\begin{array}{c}1,6 \\
13,1\end{array}$ \\
\hline
\end{tabular}

\section{Kesimpulan}

Perkebunan kopi rakyat dengan umur $>10$ tahun di lokasi penelitian mengemisikan karbon sebesar 47 ton $\mathrm{CO}_{2}$-e/ha dan terdapat cadangan karbon sebesar 91,4 ton $\mathrm{C} /$ ha. Strategi adaptasi terhadap perubahan iklim dapat dilakukan dengan penerapan GAP, penggunaan varietas/klon tahan kekeringan, dan penggunaan mulsa organik, lebih banyak pohon penaung dan sistem tumpang sari, pembuatan rorak dan biopori.

\section{Daftar Pustaka}

Abdoellah (2016). Kopi dan lingkungan hidup: Sejarah botani, proses produksi, pengolahan produk hilir dan system kemitraan. Yogyakarta, Gadjah Mada University Press. p. 890.

Abera G \& EW Meskel (2013). Soil properties and soil organic carbon stocks of tropical andosol under different land uses. Soil Science 3 , 153-162. http://dx.doi.org/10.4236/ojss.2013.33018.

Alemu A \& E Dufera (2017). Climate smart coffee (coffea arabica) production. American Journal of Data Mining and Knowledge Discovery 2(2), 62-68. doi: 10.11648/j.ajdmkd.20170202.14.

Ayalev T (2014). Characterization of organic coffee production, certification and marketing system: Ethiopia as a main indicator: a review. Asian Journal of Agriculture Research 8 (4),170-180. Doi:10.3923/ajar.2014.170.180.
Balafoutis A, B Beck, S Fountas, J Vangeyte, T van der Wal, I Soto, MG Barbero, A Barnes \& V Eory (2017). Precision agriculture technologies positively contributing to GHG emissions mitigation, farm productivity and economics. Sustainability 9 (1339), 1-28. Doi:10.3390/su9081339.

Barthod J, C Rumpel, R Paradelo \& MF Dignac (2016). The effects of worms, clay and biochar on $\mathrm{CO} 2$ emissions during production and soil application of co-composts. SOIL 2, 673-683. Doi:10.5194/soil-2-673-2016.

Berisso FE, P Schjønning, T Keller, M Lamandé, A Simojoki, BV Iversen, L Alakukku \& J Forkman (2013). Gas transport and subsoil pore characteristics: anisotropy and long-term effects of compaction. Geoderma 195-196, 184-191.

Blagodatsky S \& P Smith (2012). Soil physics meets soil biology: towards better mechanistic prediction of greenhouse gas emissions from soil. Soil Biol Biochem 47, 78-92.

Brockett BFT, CE Prescott \& SJ Grayston (2011). Soil moisture is the major factor influencing microbial community structure and enzyme activities across seven biogeoclimatic zones in western Canada. Soil Biology and Biochemistry $44 \quad$ (1), 9-20. https://doi.org/10.1016/j.soilbio.2011.09.003. 
Craparo ACW, Van Asten PJA, Läderach P, Jassogne LTP \& Graba SW (2015). Coffea arabica yields decline in Tanzania due to climate change: Global implications. Agricultural and Forest Meteorology 207, 110. https://doi.org/10.1016/j.agrformet.2015. 03.005 .

Ditjenbun (2016). Statistik perkebunan Indonesia komoditas kopi 2015-2017. Jakarta, Direktorat Jenderal Perkebunan. p. 83.

ESRL (Earth System Research Laboratory) (2018). Trends in atmospheric carbon dioxide. Taken from http://www.esrl.noaa.gov/gmd/ ccgg/trends/. [diakses 16 Maret 2018]

Flessa H, M Potthoff \& N Loftfield (2002). Integrated evaluation of greenhouse gas emissions $\left(\mathrm{CO}_{2}, \mathrm{CH}_{4}, \mathrm{~N}_{2} \mathrm{O}\right)$ from two farming system in southern Germany. Agriculture, Ecosystems and Environment 91, 175-189.

Graham RF, SE Wortman \& CM Pittelkow (2017). Comparison of organic and integrated nutrient management strategies for reducing soil N2O emissions. Sustainability 9, 510; doi:10.3390/su9040510www.mdpi.com/journa 1/sustainability.

Hairiah K \& S Rahayu (2007). Pengukuran 'karbon tersimpan' di berbagai macam penggunaan lahan. Bogor. World. Agroforestry Centre - ICRAF, SEA Regional Office, University of Brawijaya, Unibraw, Indonesia. 77 p. 979-3198-35-4.

Hairiah K, A Ekadinata, RR Sari \& S Rahayu (2011). Pengukuran cadangan karbon: dari tingkat lahan ke bentang lahan. Petunjuk praktis. Edisi kedua. Bogor, World Agroforestry Centre, ICRAF SEA Regional Office, University of Brawijaya (UB), Malang, Indonesia.

Hanson PJ, NT Edwards, CT Garten and JA Andrews (2000). Separating root and soil microbial contributions to soil respiration: a review of methods and observations. Biogeochemistry 48 (1), 115-146.

Hergoualc'h K, E Blanchart, U Skiba, C Henault \& JM Harmand (2012). Changes in carbon stock and greenhouse gas balance in a coffee (Coffea arabica) monoculture versus an agroforestry system with Inga densiflora, in Costa Rica. Agriculture, Ecosystems and Environment 148,102-110.

Hergoualc'h K, U Skiba, JM Harmand JM \& C Hénault (2008). Fluxes of greenhouse gases from Andosols under coffee in monoculture or shaded by Inga densiflora in Costa Rica. Biogeochemistry 89, 329-345.
IAEA (International Atomic Energy Agency) (1992). Manual on Measurement of Methane and Nitrous Oxide Emissions from Agriculture, Vienna, Austria.

Kattenberg A, Giorgi F, Grassl H, Meehl G, Mitchell J, Stouffer R, Tokioka T, Weaver A \& Wigley $\mathrm{T}$ (1996). Climate models projections of future climate. In: J.T. Houghton et al., (ed) Climate Change 1995: The Science of Climate Change. NewYork (USA) .Cambridge University Press. p 285357.

Kementan (Kementerian Pertanian) (2015). Rencana strategis Kementerian Pertanian 2015-2019. Jakarta, Sekretariat Jenderal Kementerian Pertanian. p.339.

Li S, J Su, W Liu, X Lang, X Huang, C Jia, Z Zhang \& Q Tong (2015). Changes in biomass carbon and soil organic carbon stocks following the conversion from a secondary coniferous forest to a pine plantation. PLOS ONE 10(9): e0135946. https://doi.org/10. 1371/journal.pone.0135946.

Lin BB (2010). The role of agroforestry in reducing water loss through soil evaporation and crop transpiration in coffee agroecosystems. Agricultural and Forest Meteorology 150(4), 510-518. $\underline{\text { https:// }}$ doi.org/10.1016/j.agrformet.2009.11.010.

Magina F, R Makundi, A Maerere, G Maro \& J Teri (2011). Temporal variations in the abundance of three important insect pests of coffe in Kilimanjaro region, Tanzania. In: Proc 23rd International Scientific Colloquium on Coffee. Association Scientifique Internationale du Caffe (ASIC), Bali Indonesia, October 3-8, 2010. p.1114-1118.

Marinho EB, AL Oliveira, DB Zandonadi, LEC Benedito, RB Souza, CC Figueiredo \& JG Busato (2014). Organic matter pools and nutrient cycling in different coffee production systems in the Brazilian Cerrado. Agroforest Syst 88, 767-778.

Meuelenberg FP \& FD Dakora (2007). Assessing the biological potential of $\mathrm{N}_{2}$-fixing Leguminosae in Botswana for increased crop yields and commercial exploitation. African Journal of Biotechnology 6 (4), 325-334.

Muñoz C, L Paulino, C Monreal \& E Zagal (2010). Greenhouse gas $\left(\mathrm{CO}_{2}\right.$ and $\left.\mathrm{N}_{2} \mathrm{O}\right)$ emissions from soils: A review. Chilean Journal of Agricultural Research 70(3), 485497. 
Noponen MRA, GE Jonesa, JP Haggarb, G Soto, N Attarzadeha \& JR Healey (2012). Greenhouse gas emissions in coffee grown with differing input levels under conventional and organic management. Agriculture, Ecosystems and Environment 151, 6- 15. Doi:10.1016/j.agee.2012.01.019.

Ovalle-Rivera O, Läderach P, Bunn C, Obersteiner M \& Schroth G (2015). Projected shifts in Coffea arabica suitability among major global producing regions due to climate change. PLOS ONE 10(4): e 0124155.

Peng S, S Piao, T Wang, T Sun \& Shen Z (2009). Temperature sensitivity of soil respiration in different ecosystems in China. Soil Biol Biochem 41(5), 1008-1014.

Reay D, EA Davidson, KA Smith, P Smith, JM Melillo, F Dentener \& PJ Crutzen (2012). Global agriculture and nitrous oxide emissions. Nature Climate Change Review 2(6), 410-416.

Smith P \& JE Olesen (2010). Climate change and agriculture: synergies between the mitigation and adaptation to climate change in agriculture. The Journal of Agricultural Science 148 (5), 543-55.

Smith P, D Martino, Z Cai, D Gwary, H Janzen, P Kumar, B McCarl, S Ogle, F O’Mara, C Rice, B Scholes \& O Sirotenko (2007). Agriculture in climate change 2007: mitigation. In: B. Metz, O.R. Davidson, P.R. Bosch, R. Dave, L.A. Meyer (eds), Contribution of Working Group III to the Fourth Assessment Report of the Intergovernmental Panel on Climate Change. Cambridge University Press, Cambridge, United Kingdom and New York, NY, USA. p 498-540.

Suryani E \& A Dariah (2012). Peningkatan produktivitas tanah melalui sistem agroforestry. Jurnal Sumberdaya Lahan 6 (2), 101-109.

Syakir M \& E Surmaini (2017). Perubahan iklim dalam konteks sistem produksi dan pengembangan kopi di Indonesia. Jurnal Litbang Pertanian 36 (2), 77-90. Doi: 10.21082/jp3.v36n2.2017

Thangarajan R, NS Bolan, G Tian G, R Naidu \& A Kunhikrishnan (2013). Role of organic amendment application on greenhouse gas emission from soil. Science of the Total Environment. 465, 72-96. doi: 10.1016/j.scitotenv.2013.01.031.

Van Noor Wijk M, S Rahayu, K Hairiah, Y C Wulan, A Farida \& B Verbist (2002). Carbon stock assessment for a forest to coffee conversion landscape in Sumber Jaya (Lampung Indonesia): From allometric equations to land use change analysis. Science in China 45:75-86.

Velmourougane K (2016). Impact of organic and conventional systems of coffee farming on soil properties and culturable microbial diversity. Scientifica 2016, p. $1-9$. http://dx.doi.org/10.1155/2016/3604026 .

Verchot LV, L Hutabarat, K Hairiah \& van Noordwijk M (2006). Nitrogen availability and soil $\mathrm{N}_{2} \mathrm{O}$ emissions following conversion of forests to coffee in southern Sumatra. Global Biogeochemical Cycles 20, GB4008, doi:10.1029/2005GB002469

Wibawa A, F Yuliasmara \& R Erwiyono (2010). Estimasi cadangan karbon pada perkebunan kopi di Jawa Timur. Pelita Perkebunan 26(1), $1-11$.

Willey Z \& B Chameides (2007). Harnessing farms and forests in the low carbon economy: how to create, measure and verify greenhouse gas offsets. Duke University Press. Nicholas Institute for Environmental Policy Solutions. North Carolina, US. 231 p. ISBN: 978-08322-4168-0.

Wu X, Z Yao, N Brüggemann, Z Shen, B Wolf, M Dannenmann, X Zheng \& K ButterbachBahl (2010). Effects of soil moisture and temperature on $\mathrm{CO}_{2}$ and $\mathrm{CH}_{4}$ soil-atmosphere exchange of various land use/cover types in a semi-arid grassland in Inner Mongolia, China. Soil Biol Biochem 42 (5), 773-787.

Yuliasmara F (2016). Strategi mitigasi perkebunan kopi menghadapi perubahan iklim. Warta Pusat Penelitian Kopi dan Kakao 28(3), 1-7.

Zhou WJ, H Ji, J Zhu, YP Zhang, LQ Sha, YT Liu, X Zhang, W Zhao, Y Dong, XL Bai, YX Lin, JH Zhang \& XH Zheng (2016). The effects of nitrogen fertilization on $\mathrm{N}_{2} \mathrm{O}$ emissions from a rubber plantation. Sci Rep 6, 28230. Doi: $10.1038 /$ srep28230. 